\title{
PENGARUH PENGELUARAN KONSUMSI DAN INVESTASI PEMERINTAH TERHADAP PERTUMBUHAN EKONOMI DI INDONESIA
}

\author{
AHMAD YANI KOSALI \\ Sekolah Tinggi Ilmu Administrasi (STIA) Satya Negara Palembang \\ E-mail : yanikosali@gmail.com
}

\begin{abstract}
ABSTRAK
Penelitian ini bertujuan untuk mendeskripsikan keterkaitan antara pengeluaran pemerintah dengan pertumbuhan ekonomi Indonesia periode 1997-2007.Dalam penelitian ini, belanja pemerintah pusat dibedakan menjadi belanja berjalan dan belanja modal. Data diambil dari Badan Pusat Statistik, International Funding Statistik (IFS) dan Asian Development Bank (ADB).Analisis menggunakan kualitatif dan kuantitatif.Analisis kualitatif dijelaskan secara deskriptif tentang pengeluaran pemerintah di Indonesia.Analisis kuantitatif menggunakan Ordinary Least Squares (OLS) dengan data sekunder.Hasil penelitian Regresi menunjukkan bahwa: (1) pengeluaran saat ini memiliki hubungan positif dengan pertumbuhan ekonomi dan pengaruhnya signifikan secara statistik.(2) Belanja modal memiliki hubungan positif dengan pertumbuhan ekonomi dan pengaruhnya signifikan secara statistik.

Kata kunci: pengeluaran pemerintah, pengeluaran saat ini, belanja modal, pertumbuhan ekonomi
\end{abstract}

\begin{abstract}
This research was aimed at describing connections between government expenditures to Indonesia's economic growth in the period 1997-2007. In this research, central government expenditure can be divided into current expenditure and capital expenditure. The data were taken from Badan Pusat Statistik, International Funding Statistik (IFS) and Asian Development Bank (ADB). The analysis use qualitative and quantitative. Qualitative analysis described in descriptive about government expenditures in Indonesia. The quantitative analysis used Ordinary Least Squares (OLS) with secondary data. The Regression of research results show that: (1)current expenditure has a positive relationship to economic growth and the effect statistically significant. (2) capital expenditure has a positive relationship to economic growth and the effect statistically significant.

Keywords: government expenditure, current expenditure,capital expenditure, economic growth
\end{abstract}

\section{PENDAHULUAN}

Berbagai kemajuan dan perkembangan pembangunan telah dicapai dan telah berhasil meningkatkan perekonomian indonesia. Salah satu indikator keberhasilan tersebut terlihat dari rata-rata pertumbuhan ekonomi Indonesia yang mencapai 5,11\% per tahunnya pada periode penelitian. Angka rata-rata pertumbuhan ekonomi tersebut menunjukkan bahwa kinerja pembangunan Indonesia cukup tinggi. Hal ini tidak 
terlepas dari peran serta masyarakat, pemerintah, para pelaku ekonomi, dan juga pihak luar negeri. Selain tingkat pertumbuhan yang tinggi, pesatnya pembangunan ekonomi pun membawa dampak pada meningkatnya standar hidup dan kesejahteraan masyarakat, dimana peningkatan standar hidup ini tidak hanya peningkatan pendapatan saja tetapi juga peningkatan permintaan terhadap barang dan jasa public baik dari segi kualitas maupun kuantitas. Penyelenggaraan barang dan jasa publik ini secara langsung merupakan tanggung jawab utama pemerintah karena ciri utama dari barang dan jasa public itu sendiri yang menyangkut kepentingan masyarakat luas.

Dalam perekonomian modern bahwa penggunaan sumber daya tidak hanya untuk investasi dan konsumsi juga untuk penggunaan publik. Sebagai contoh di USA bahwa kurang lebih $20 \%$ dari total output dibelanjakan oleh pemerintah untuk kepentingan public tersebut, bahkan di banyak Negara angkanya bahkan lebih besar (Syafarudin,2003).

Besarnya penyediaan fasilitas publik ini mempunyai korelasi terhadap besarnya pengeluaran pemerintah. Pengeluaran pemerintah suatu negara menggambarkan suatu pembiayaan terhadap kegiatan pemerintah. Seperti telah diketahui, pengeluaran pemerintah melalui Anggaran Pendapatan dan Belanja Negara(APBN) tercermin dalam realisasi anggaran belanja rutin dan realisasi anggaran belanja pembangunan, sedangkan jumlah seluruh penerimaan meliputi penerimaan dalam negeri dan penerimaan luar negeri yang disebut penerimaan pembangunan. Ditinjau dari tujuannya, pengeluaran rutin merupakan pengeluaran operasional dan mutlak harus dilakukan serta dikategorikan sebagai pengeluaran konsumsi (current expenditure), misalnya seperti belanja pembelian inventaris kantor, belanja pemeliharaan gedung kantor,dan lain- lain. Sebaliknya terdapat elemen pengeluaran pembangunan yang sebagian besar merupakan pengeluaran untuk investasi (capital expenditure) dapat dikategorikan sebagai pengeluaran yang bersifat konsumsi, seperti berbagai jenis upah dan gaji tambahan. Dari kedua jenis pengeluaran tersebut, pengeluaran pembangunanlah yang memiliki sumbangan terbesar dalam pembentukan modal tetap bruto nasional yang dilakukan pemerintah pusat (Matriks Investasi Pemerintah BPS).

Pengeluaran pemerintah dalam hal ini pengeluaran investasi pemerintah memiliki kedudukan yang strategis dalam meningkatkan laju pertumbuhan ekonomi nasional. Sering pula dikatakan bahwa pengeluaran investasi pemerintah dapat memainkan peran sebagai salah satu penggerak utama (prime mover) dalam perekonomian, sehingga ketika perekonomian sedang mengalami kelesuan akibat adanya resesi ekonomi yang memerosotkan kemampuan masyarakat dalam melakukan kegiatan perekonomian, pemerintah melalui instrumen kebijakan yang dimiliki dapat tampil menyelamatkan keadaan dengan memperbesar pengeluaran pemerintah melalui anggaran belanja defisit, dan sebaliknya.

Dalam setiap sistem perekonomian, baik kapitalis atau sistem perekonomian sosialis, pemerintah senantiasa mempunyai peranan yang penting. Peranan pemerintah sangat besar dalam sistem perekonomian sosialis dan sangat terbatas dalam system kapitalis. Adam Smith mengemukakan teori bahwa pemerintah hanya mempunyai tiga fungsi:

1.Fungsi pemerintah untuk memelihara keamanan dalam negeri dan pertahanan.

2. Fungsi pemerintah untuk menyelenggarakan peradilan.

3. Fungsi pemerintah untuk menyediakan barang-barang yang tidak disediakan oleh pihak swasta, seperti halnya dengan jalan, bendungan dan lain sebagainya. 
Dalam penelitian Gwartney, Lawson dan Holcombe (1998), menyebutkan bahwa pemerintah mempunyai fungsi sebagai core function. Fungsi ini dapat membuat peningkatan dalam efisiensi perekonomian dan seterusnya dapat meningkatkan pertumbuhan. Ada dua kategori dalam fungsi ini yang kebanyakan digunakan dalam berbagai penelitian, yaitu; fungsi sebagai pelindung (protective function) dan fungsi sebagai penyedia barang-barang public (provision of a limited set of collective goods). Protective function termasuk didalamnya penegakan peraturan dan hokum dan hak-hak individu yang dapat melindumgi masyarakat dari kehilangan hak-haknya. Fungsi yang kedua yaitu provision of a limited set of collective goods, adalah menyediakan barangbarang atau jasa seperti pertahanan, jalan pendidikan dan layanan masyarakat lainnya serta barang-barang yang tidak disediakan atau disediakan dalam jumlah yang sedikit sekali oleh sector swasta. Dengan tersedianya barang-barang seperti disebutkan diatas dan perlindungan hak kepemilikan dapat meningkatkan pertumbuhan PDB (Burda dan Wyplosz, 2001).

Pengeluaran pemerintah secara garis besar terdiri dari pengeluaran rutin dan pengeluaran pembangunan. Pengeluaran konsumsi pemerintah tercakup dalam pengeluaran rutin dan pengeluaran investasi pemerintah tercakup dalam pengeluaran pembangunan. Dinegara-negara berkembang pengeluaran terbesar dialokasikan untuk pembangunan infrastruktur yang merupakan barang publik murni yang tidak dapat dihasilkan oleh pihak swasta seperti energi, pertahanan, dan juga untuk membiayai kegiatan sosial seperti pendidikan, kesehatan, dan lain-lain. Pembiayaannya dilaksanakan dengan prinsip kemampuan membayar (Syamsi:1994). Selain itu, ha lini pun berkaitan dengan meningkatnya defisit fiscal dinegara berkembang, karena keterbatasan kemampuan negara dalam meningkatkan penerimaannya untuk membiayai pengeluaran pemerintah yang semakin tinggi.

Peranan dan besarnya pengeluaran konsumsi dan investasi pemerintah menjadi sesuatu yang mengundang kontroversi pada ekonomi makro. Sementara negara-negara bergerak menuju pasar terbuka dan bebas, pengeluaran konsumsi pemerintah telah meningkat secara terus-menerus.

\section{KAJIAN TEORI}

Pertumbuhan Ekonomi

Pertumbuhan ekonomipada dasarnya diartikan sebagai suatuproses dimana PDB riil atau pendapatan riil perkapita meningkat secara terus menerus melalui kenaikan produktivitas per kapita (Salvatore:1977).

Pertumbuhan ekonomi yang dinyatakan dengan peningkatan output dan pendapatan riil perkapita memang bukanlah satu-satunya sasaran kebijaksanaan dinegara-negara berkembang, namun kebijaksanaan ekonomi menaikkan tingkat pertumbuhan output perlu dilakukan karena:

1. Pertumbuhan ekonomi dipandang sebagai suatu syarat yang sangat diperlukan untuk perbaikan kesejahteraan masyarakat.

2. Pertumbuhan ekonomi dipandang sebagai suatu prasyarat untuk mencapai tujuantujuan pembangunan lainnya, seperti: peningkatan pendapatan dan kekayaan masyarakat, ataupun penyediaan fasilitas dan sarana sosiallainnya(Thirwall:1976).

Menurut Kuznets, pertumbuhan ekonomi adalah kenaikan kapasitas dalam jangka panjang dari negara yang bersangkutan untuk menyediakan berbagai barang ekonomi kepada penduduknya. Kenaikan kapasitasitu sendiri ditentukan atau 
dimungkinkan oleh adanya kemajuan atau penyesuaian-penyesuaian yang bersifat teknologi, institusional (kelembagaan) dan ideologis terhadap berbagai tuntutan keadaan yang ada (Todaro:1994).

Kuznets mengemukakan enam karakteristik atau cirri proses pertumbuhan ekonomi yang bisa ditemui dihampir semua negara maju, yaitu:

a. Tingkat pertumbuhan output per kapita dan pertambahan penduduk yang tinggi.

b. Tingkat kenaikan total produktivitas faktor yang tinggi, khususnya produktivitas tenaga kerja.

c. Tingkat transformasi structural ekonomi yang tinggi.

d. Tingkat transformasi sosial dan ideology yangtinggi.

e. Adanya kecenderungan negara-negara yang mulai atau yang sudah maju perekonomiannya untuk berusaha merambah bagian-bagian dunia lainnya sebagai pemasaran dan sumber bahan baku.

f. Terbatasnya penyebaran pertumbuhan ekonomi yang hanya mencapai sepertiga bagian penduduk dunia.

Menurut teori pertumbuhan ekonomi neo-klasik, dengan mengasumsikan luas lahan tetap, makayang mempengaruhi pertumbuhan adalah meningkatan pada penawaran tenaga kerja, peningkatan pada Kapital stock dan peningkatan pada produktivitas.

Meningkatnya penawaran tenaga kerja akan menyebabkan bertambahnya output. Real output meningkat bila semakin banyak orang yang ikut serta dalam proses produksi suatu negara. Peningkatan modal dapat dibagi menjadi dua, yaitu ;peningkatan pada modal fisik dan modal tenaga kerja. Modal fisik meningkatkan output dikarenakan hal tersebut merangsang produktivitas tenaga kerja dan secara langsung menyediakan pelayanan yang berharga. Peningkatan pada produktivitas akan terjadi ketika investasi pada peralatan seperti computer dan mesin yang dapat mengurangi jam kerja tenaga kerja.

Modal tenaga kerja meningkatkan pertumbuhan ekonomi karena tenaga kerja yang mempunyai skill lebih produktif dibandingkan dengan mereka yang tidak. Investasi pada modal tenaga kerja dapat dilakukan melalui pendidikan atau pelatihan. Peningkatan produktivitas menjelaskan peningkatan pada output yang tidak dapat dijelaskan oleh pertambahan input. Yang terpenting dari produktivitas adalah dengan adanya kemajuan teknologi, yang mempengaruhinya dengan 2 cara. Pertama adalah kemajuan pada pengetahuan yang disebut inventions dan kedua adalah penggunaan dari pengetahuan itu sendiri yang menyebabkan produksi yang lebih efisien yang disebut inovasi. (Burda danWyplosz,2001)

Perkembangan perekonomian suatu Negara dapat ditunjukkan oleh pertumbuhan Produk Domestik bruto (PDB) Negara tersebut. PDB merupakan nilai dari total output yang dihasilkan oleh suatu Negara. Selama kurun waktu tersebut, PDB Indonesia terus meningkat sementara pertumbuhannya mengalami fluktuasi dengan laju pertumbuhan rata-rata sebesar $5,12 \%$ pertahun.

Laju pertumbuhan ekonomi Indonesia berfluktuasi dari tahun ke tahun walaupun secara umum dapat kita tarik kesimpulan bahwa pertumbuhannya cenderung membaik terutama setelah pemerintah memberlakukan kebijakan-kebijakan ekonomi sehingga tercipta suasana perekonomian yang kondusif. Pada saat krisis ekonomi melanda Asia, Indonesia tidak terkecuali terkena dampaknya bahkan mungkin yang terparah, tetapi saat ini perekonomian Indonesia sudah mulai bangkit lagi. 


\section{Pengeluaran Investasi Pemerintah}

Dalam neraca anggaran pendapatan dan Belanja negara, pengeluaran pemerintah Indonesia secara garis besar dikelompokkan atas pengeluaran rutin dan pengeluaran pembangunan. Klasifikasi ini mirip seperti klasifikasi pengeluaran ke dalam pos-pos pengeluaran lancer dan pos-pos pengeluaran kapital.

Pengeluaran rutin pada dasarnya berunsurkan pos-pos pengeluaran untuk membiayai pelaksanaan roda pemerintahan sehari-hari,meliputi belanja pegawai, belanja barang, berbagai macam subsidi (subsidi daerah dan subsidi harga barang); angsuran dan bunga utang pemerintah; serta sejumlah pengeluaran lain. Sedangkan pengeluaran pembangunan maksudnya pengeluaran yang bersifat menambah modal masyarakat dalam bentuk prasarana fisik, dibedakan atas pengeluaran pembangunan yang dibiayai dengan dana rupiah dan bantuan proyek.

Identitas keseimbangan pendapatan nasional $\mathrm{Y}=\mathrm{C}+\mathrm{I}+\mathrm{G}+\mathrm{X}-\mathrm{M}$ merupakan "sumber legitimasi" pandangan kaum Keynesian akan relevansi campur tangan pemerintah dalam perekonomian. Darinotasi yang sangat sederhana tersebut dapat ditelaah bahwa kenaikan (penurunan) pengeluaran pemerintahakan menaikan (menurunkan) pendapatan nasional (Dumairy:1997).

Banyak pertimbangan yang mendasari pengambilan keputusan pemerintahdalam mengatur pengeluarannya. Pemerintah tidak cukup hanya meraih tujuan akhir dari setiap kebijaksanaan pengeluarannya, tetapi juga harus memperhitungkan sasaran antara yang akan menikmati atau terkena kebijaksanaan tersebut. Memperbesar pengeluaran dengan tujuan semata-mata untuk meningkatkan pendapatan nasional atau memperluas kesempatan kerja adalah tidak memadai, melainkan harus pula diperhitungkan siapa (masyarakat lapisan mana) yang akan terpekerjakan atau meningkat pendapatannya.

WW Rostow dan RA Musgrave menghubungkan pengeluaran pemerintah dengan tahap-tahap pembangunan ekonomi. Pada tahap awal pembangunan ekonomi, menurut mereka, rasio investasi pemerintah terhadap investasi total-dengan perkataan lain juga rasio pengeluaran pemerintah terhadap pendapatan nasional relative besar. Karena pemerintah harus menyediakan berbagai sarana dan prasarana. Pada tahap menengah pembangunan ekonomi, investasi pemerintah tetap diperlukan guna memacu pertumbuhan agar dapat lepas landas. Bersamaan dengan itu porsi investasi pihak swasta juga meningkat. Tahap besarnya peranan pemerintah adalah karena pada tahap ini banyak terjadi kegagalan pasar yang ditimbulkan oleh perkembangan ekonomi itu sendiri.

Data yang digunakan untuk menunjukkan perkembangan investasi pemerintah pada penelitian ini adalah data realisasi pengeluaran pembangunan pemerintah. Pengeluaran pembangunan merupakan pengeluaran yang berkaitan dengan kegiatan investasi yang dilaksanakan oleh pemerintah untuk merealisasikan sasaran-sasaran dari program pembangunan. Anggaran pembangunan dialokasikan terutama untuk membiayai proyek-proyek yang tidak dapat dibiayai sendiri oleh masyarakat. Pengeluaran pembangunanlah yang memiliki sumbangan terbesar dalam pembentukan modal tetap bruto nasional yang dilakukan pemerintah pusat.

\section{Pengeluaran Konsumsi Pemerintah}

Seperti telah diketahui, pengeluaran pemerintah melalui Anggaran Pendapatan dan Belanja Negara (APBN) tercermin dalam realisasi anggaran belanja rutin dan 
realisasi anggaran belanja pembangunan, sedangkan jumlah seluruh penerimaan meliputi penerimaan dalam negeri dan penerimaan luar negeri yang disebut penerimaan pembangunan. Ditinjau dari tujuannya, pengeluaran rutin merupakan pengeluaran operasional dan mutlak harus dilakukan serta konsumtif, tetapi tidak semua anggaran belanja rutin dapat dikategorikan sebagai pengeluaran konsumsi (current expenditure), misalnya seperti belanja pembelian inventaris kantor, belanja pemeliharaan gedung kantor,dan lain- lain.

Pengeluaran konsumsi yaitu pengeluaran rutin Negara dalam hal ini belanja pegawai yang mencakup gaji dan pensiun, tunjangan serta belanja barang-barang dalam negeri, dana rutin daerah dan pengeluaran rutin lainnya yang berdampak konsumsi pegawai atau masyarakat terhadap barang-barang meningkat yang kemudian menaikkan fungsi konsumsi yang menyumbang kontribusi terhadap bruto nasional dan pertumbuhan ekonomi.

\section{Kerangka pikir Konseptual}

Pertumbuhan ekonomi merupakan perluasan kapasitas suatu perekonomian dalam menghasilkan barang dan jasa, yang diukur melalui peningkatan Produk Domestik Bruto (PDB). Dalam kerangka teori Keynesian, berbagai jenis pengeluaran public ini memberikan kontribusi yang positif terhadap pertumbuhan ekonomi. Tingkat pengeluaran pemerintah yang tinggi dapat meningkatkan jumlah tenaga kerja dan investasi melalui angka pengganda (multiplier effect) permintaan agregat. Dengan demikian, pengeluaran pemerintah dapat meningkatkan permintaan agregat, yang pada akhirnya dapat meningkatkan output tergantung pada besarnya dan efektivitas angka pengganda pengeluaran tersebut.

Pendapat WWRostow dan RA Musgrave dalam Buku Ekonomi Publik (Goeritno:1995) menghubungkan pengeluaran pemerintah dengan tahap-tahap pembangunan ekonomi. Pada tahap awal rasio investasi pemerintah terhadap pendapatan nasional relatif besar. Hal ini disebabkan karena pada tahap ini pemerintah harus menyediakan sarana dan prasarana. Pada tahap menengah, investasi pemerintah tetap diperlukan untuk meningkatkan pertumbuhan ekonomi, dan peranan investasi swasta pada tahap ini sudah semakin besar.

Teori pertumbuhan Neo- klasik melihat dari sudut pandang yang berbeda, yaitu segi penawaran. Teori ini pertumbuhan ekonomi tergantung kepada pengembangan faktor-faktor produksi, yaitu pertambahan modal dan produktivitas modal marjinal, pertambahan tenaga kerja dan produktivitas tenaga kerja marjinal, serta perkembangan teknologi (Todaro,1990).

\section{Metode Penelitian}

Penelitian ini terbatas pada pengujian sampai sejauh mana variabel pengeluaran investasi pemerintah dan pengeluaran konsumsi pemerintah mempengaruhi variabel tidak bebas, pertumbuhan ekonomi. Analisis dilakukan dengan menggunakan data tahunan selama 11 tahun,dari tahun 1997 sampai dengan tahun 2007. Data-data yang digunakan dalam penelitian ini adalah data sekunder yang diperoleh dari Badan Pusat Statistik,Bank Indonesia, International Monetary Fund,Asian Development Bank, dan International Funding Statistik (IFS). Secara spesifik data yang digunakan adalah sebagai berikut :

\section{Pertumbuhan ekonomi (Y)}


Data pertumbuhan ekonomi yang digunakan adalah data pertumbuhan PDB riil atas dasar harga konstan tahun 1990. Sumber datanya diperoleh dari International Funding Statistik (IFS).

2. Pengeluaran konsumsi pemerintah(Gc)

Data pengeluaran rutin pemerintah digunakan sebagai proksi dari konsumsi pemerintah. Data ini dijadikan sebagai rasio dari PDB. Dalam penelitian ini tidak dilakukan pemisahan antara pengeluaran rutin yang merupakan pengeluaran konsumsi dan pengeluaran rutin yang merupakan pengeluaran investasi. Sumber datanya diperoleh dari BPS dan Asian Development Bank (ADB).

3. Pengeluaran investasi pemerintah(Gi)

Data pengeluaran pembangunan pemerintah digunakan sebagai berkaitan dengan permasalahan yang sedang diteliti. Sedangkan untuk analisis kuantitatif digunakan alat bantu ekonometrika untuk mendapatkan gambaran yang jelas tentang hubungan antara variabel-variabel yang digunakan dalam penelitian ini.

\section{Spesifikasi Model Ekonometrik}

Model ekonometrik yang digunakan dalam penelitian ini diadopsi dari model yang dikembangkan oleh Peter Sjoberg (2003). Model ini digunakan untuk mengetahui bagaimana pengeluaran pemerintah dan variabel-variabel ekonomi lainnya mempengaruhi pertumbuhan ekonomi. Model ekonometrik penelitian ini diformulasikan sebagai berikut:

$\mathrm{Yt}=\beta+\beta+\beta+\varepsilon+02$ dimana :

$\mathrm{Gct}=$ rasio konsumsi pemerintah terhadap PDB pada tahun $\mathrm{t}$

Gi $t=$ rasio investasi pemerintah terhadap PDB pada tahun $\mathrm{t}$

$t=$ error terms

\section{HASIL DAN PEMBAHASAN \\ Interpretasi Model}

Pada bagian ini akan diungkapkan pengaruh pengeluaran konsumsi pemerintah dan pengeluaran investasi pemerintah terhadap pertumbuhan ekonomi di Indonesia. Untuk pengolahan data, alat bantu yang digunakan adalah software Eviews4.1. berikut:

Berdasarkan hasil pengolahan data, didapat persamaan regresi ganda sebagai

Yt $\square \square 0 \square \square t G c t \square \square 2$ Git $\square \square t$

$\mathrm{Yt}=77379.66+6.031608 \mathrm{Gct}+$

4.743162 Git+E

(0.868144) (5.455496) (4.845605)

Berikut ini adalah nilai-nilai hasil uji statistic lainnya,yaitu:

\begin{tabular}{|l|c|}
\hline R-squared & 0.967779 \\
\hline AdjustedR-squared & 0.959724 \\
\hline S.E.ofregression & 136526.1 \\
\hline
\end{tabular}




\begin{tabular}{|l|c|}
\hline Sumsquaredresid & $1.49 \mathrm{E}+11$ \\
\hline Loglikelihood & -143.9238 \\
\hline Durbin-Watsonstat & 3.112801 \\
\hline Meandependent var & 1209026. \\
\hline S.D.dependent var & 680287.0 \\
\hline Akaikeinfocriterion & 26.71342 \\
\hline Schwarzcriterion & 26.82194 \\
\hline F-statistic & 120.1431 \\
\hline Prob(F-statistic) & 0.000001 \\
\hline
\end{tabular}

Dari uji F-statistik yang signifikan sampai dengan tingkat kepercayaan 0.00000 dan nilai Adj.R2 yang sebesar $95.97 \%$ dapat dinyatakan bahwa persamaan model yang terbentuk baik. Adapun kenaikan pengeluaran konsumsi pemerintah dan pengeluaran investasi pemerintah yang bertanda positif akan mengakibatkan pertumbuhan ekonomi menguat. Ini berarti bahwa pertumbuhan ekonomi dapat dijelaskan dengan baik oleh pergerakan variabel-variabel bebasnya.

Nilai Durbin Watson (DW) dari persamaan adalah 3.112801. Sementara itu, untuk nilai $\mathrm{n}=11$ dan $\mathrm{k}=3$. Dari hasil test ini $\mathrm{P}$-value $=0.066194 \square 0.05$ maka terima $\mathrm{H} 0$. Dengan tingkat keyakinan 95\% dapat disimpulkan bahwa tidak ada otokorelasi antar variabel.

Hasil uji White Heterocedasticity Test menghasilkan nilai sebagai berikut :

Obs*R-squared: 9.116422

Probability : 0.104510

Hasil uji tersebut dengan P-Value sama dengan 0.104510 menunjukkan bahwa H0 yang menyatakan tidak ada heteroskedastisitas (homoskedastisitas) pada residual diterima pada tingkat signifikansi 5\%. Jadi, dengan tingkat keyakinan $95 \%$ pada data tersebut tidak terjadi heteroskedastisitas.

Nilai Durbin Watson yang dihasilkan sebesar 3.112801 sedangkan nilai adj. R2nya sebesar 0.959724. Jadi, nilai Durbin Watson lebih besar dari nilai R2-nya sehingga tidak mengindikasikan adanya regresi lancing sebagai akibat non- stasionaritas variabelvariabel. Adj.R2 $\square \mathrm{dW}$, merupakan indikasi adanya regresi lancung/spurious regression. Dengan demikian dapat dinyatakan bahwa terdapat hubungan antara variabel-variabel bebas dan variabel tak bebas.

Distribusi residual yang dihasilkan menunjukkan bahwa asumsi normalitas residual terpenuhi. Hal ini terlihat dari metode histogram dan Jarque-Berra yang digunakan, dimana nilai-P yang diperoleh cukup tinggi. H0: error term terdistribusi normal,danH1 :error term tidak terdistribusi normal. Nilai-P sebesar 0,903543 lebih besar dari $=5 \%$, P-value $=0,903543 \square 0.05$ maka terima H0. Dengan tingkat keyakinan $95 \%$ maka dapat dikatakan error term terdistribusi normal.

\section{KESIMPULAN}

Berdasarkan pada teori-teori dan pembuktian baik secara empiris maupun ekonomi mengenai hubungan antara pengeluaran konsumsi pemerintah dan pengeluaran investasi terhadap pertumbuhan ekonomi, maka dapat disimpulkan bahwa Pengeluaran 
konsumsi pemerintah dan pengeluaran investasi pemerintah di Indonesia mempunyai kecenderungan untuk meningkat setiap tahunnya. Terdapat hubungan yang positif pengeluaran konsumsi pemerintah dengan pertumbuhan ekonomi pada periode penelitian. Hal ini dikarenakan pengeluaran konsumsi yaitu pengeluaran rutin Negara dalam hal ini belanja pegawai yang mencakup gaji dan pensiun,tunjangan serta belanja barang-barang dalam negeri, dana rutin daerah dan pengeluaran rutin lainnya yang berdampak konsumsi pegawai atau masyarakat terhadap barang-barang meningkat yang kemudian menaikkan fungsi konsumsi yang menyumbang kontribusi terhadap bruto nasional dan pertumbuhan ekonomi.

Pengeluaran investasi pemerintah mempunyai dampak yang positif terhadap pertumbuhan ekonomi. Karena pengeluaran investasi pemerintah dimaksudkan guna menunjang pertumbuhan ekonomi dan mendorong berkembangnya kegiatan ekonomi masyarakat. Dan anggaran pembangunan dialokasikan terutama untuk membiayai proyek-proyek yang tidak dapat dibiayai sendiri oleh masyarakat.

\section{DAFTAR PUSTAKA}

Badan Pusat Statistik. Indikator Ekonomi, berbagai edisi.

Badan Pusat Statistik. Statistik dalam 50 Tahun Indonesia Merdeka.

Badan Pusat Statistik. Statistik Indonesia, berbagai edisi.

Badan Pusat Statistik. Matriks Investasi pemerintah, Tahun 1996/1997-1998/1999.

Bank Indonesia. Statistik Ekonomi Keuangan Indonesia, berbagai edisi.

Dumairy. 1997. Perekonomian Indonesia. Jakarta : Erlangga..

Goeritno Mangkoesoebroto. Ekonomi Publik, Edisi III. Yogyakarta : BPFE, 1995.

Gujarati, Damodar. 2003. N. Basic Econometrics. Fourth Edition. McGraw-Hill Higher Education,

Ibnu Syamsi S.U. 1994. Dasar-dasar Kebijaksanaan Keuangan Negara, Jakarta: Rineka Cipta,

Ram, R.. 1986. Government Size and Economic Growth : A New Framework and Some Evidence from Cross-Section a land Time- Series Data, American Economic Review, 76,191-202,

Ram, R.,1989. GovernmentSize and Economic Growth: A New Framework and Some Evidence from Cross-Section a land Time-Series Data : A Reply, American Economic Review,79, 281-84,

Salvatore, D \& Dowling, E.T. 1977. Theory and Problem sat Economic Development, Mc-GrawHill, New York,

Sjoberg, P. 2003. Government 1990. Expenditures Effecton Economic Growth. Lule a University of Technology,

Syafaruddin, 2003. Intisari Buku "Advanced Macroeconomics (David Romer), Tugas Program Pascasarjana Universitas Padjajaran, Bandung,

Thirwall A.P., Finance Economic Development, London Mc Millan Press Ltd , 1976.

Todaro, Michael P. Pembangunan Ekonomi : Edisi Kelima. Bumi Aksara, 1994. . 1990. Pembangunan Ekonomi di Dunia Ketiga. Jakarta: Erlangga,

Wyplosz .C, and Burda .M. 2001. Macroeconomics: A European Text, 3rd edition 